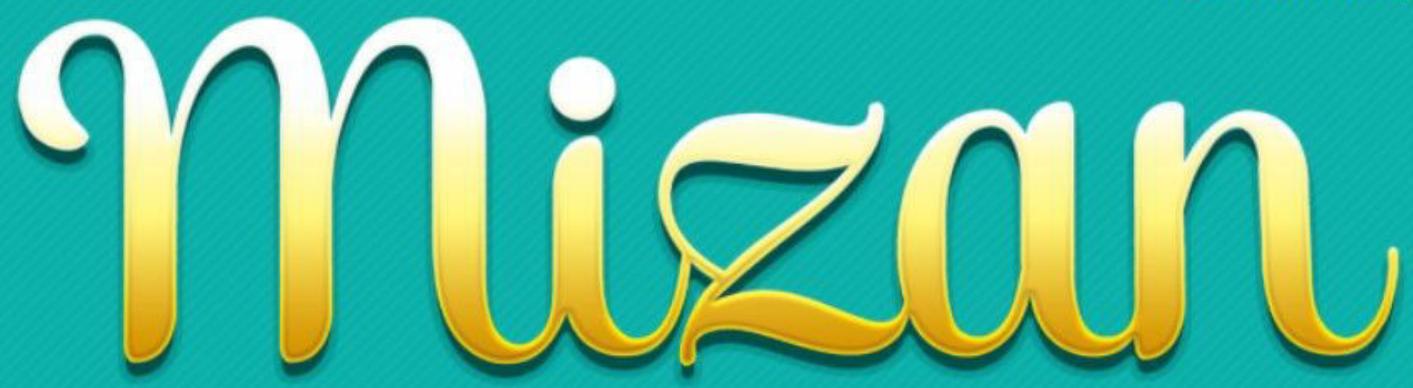

\title{
JOURNAL OF ISLAMIC LAW
}

Akses Keadilan Bagi Masyarakat Kabupaten Kepulauan Seribu

Kamarusdiana

Efektivitas Bimbingan Perkawinan Di KUA Citeureup

Dalam Menjaga Keutuhan Rumah Tangga

Yusuf Firdaus, Kholil Nawawi, Mukhtar

Penerapan Asas Audi Alteram Et Partem

Pada Perkara Judicial review Di Mahkamah Agung

Asep Syarifuddin Hidayat

Sistem Pelaksanaan Koperasi Mitra GBS

PT. Golden Blossom Sumatera Desa Prambatan

Saprida

Tinjauan Hukum Islam Tentang Asuransi

Abdul Wahab Abd Muhaimin

Perekonomian Islam Pada Masa Dinasti Fatimiyah

Fakhry Zamzam, Havis Aravik

Pemikiran Tentang Hukum Keperdataan Islam Dalam Dimensi Filsafat IImu Abu Tamrin

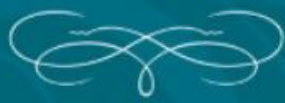

Fakultas Agama Islam

Universitas Ibn Khaldun

Bogor 


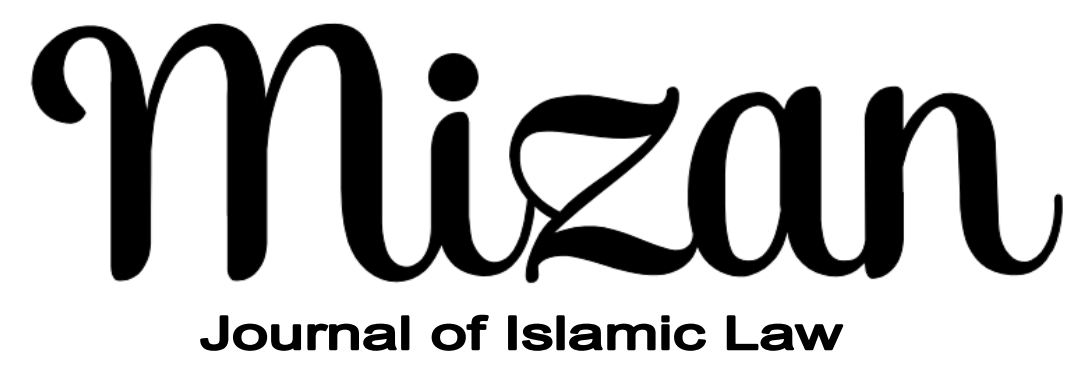

\section{VOL. 3 NO. 1 (2019)}

Mizan: Journal of Islamic Law is continuation of Mizan Ahwal Al-Syakhsiyah Journal since 2013, published by the faculty of Islamic Studies, Universitas Ibn Khaldun (UIKA) Bogor West Java, Indonesia. Mizan of Islamic Law published twice a year since 2017 (June and Desember), is a multilingual (Bahasa Indonesia, Arabic, English, and

Russian), Peer-Reviewed journal, and specialized in Islamic Law, Islamic Studies, and Sharia. This journal is published by the faculty of Islamic Studies, Universitas Ibn Khaldun Bogor, in partnership with APSI (Indonesian Sharia Advocates Association). Editors welcome scholars researchers and pratitioner of Islamic Law around the world to submit scholarly articles to be published throught this journal. All articles will be reviewed by experts before accepted for publication, each author is solely responsible for the content of published articles.

MIZAN; Journal of Islamic Law has been indexed at Google Scholar, Moraref, Sinta, and become a CrossRef Member since year 2017. Therefore, all articles published by MIZAN; Journal of Islamic Law will have unique DOI number.

[ISSN: 2598-974X, E-ISSN: 2598-6252]

\section{ADVISORY EDITORIAL BOARD}

Didin Hafidhuddin (Universitas Ibn Khaldun Bogor)

Muhammad Munir (International Islamic University Islamabad, Pakistan)

Andi Salman Maggalatung (UIN Syarif Hidayatullah Jakarta)

Ending Bahruddin (Universitas Ibn Khaldun Bogor)

Ahmad Mukri Aji (UIN Syarif Hidayatullah Jakarta)

Muhammad Kholil Nawawi (Universitas Ibn Khaldun Bogor)

Hendri Tanjung (Universitas Ibn Khaldun Bogor)

Irfan Syauqi Beik (Institut Pertanian Bogor)

Nur Rohim Y (Kazan Federal University, KFU Russia)

\section{EDITOR IN CHIEF}

Syarifah Gustiawati Mukri

$$
\begin{gathered}
\text { EDITORS } \\
\text { Suyud Arif } \\
\text { Sutisna } \\
\text { Yono }
\end{gathered}
$$

\section{ASSISTANT TO THE EDITORS}

Siti Anisaul Kamilah

\section{Redaktur Office}

Fakultas Agama Islam Universitas Ibn Khaldun Bogor Jawa Barat

Jl. KH. Sholeh Iskandar KM. 2 Kedung Badang Tanah Sareal Bogor 16162

Telp. (62-251) 8356884, Faks. (62-251) 8356884

Website: http://www.jurnalfai-uikabogor.org/index.php/mizan,

E-mail: mizan@uika-bogor.ac.id

Permalink: https://uika-bogor.academia.edu/JurnalMizanUIKABogor 


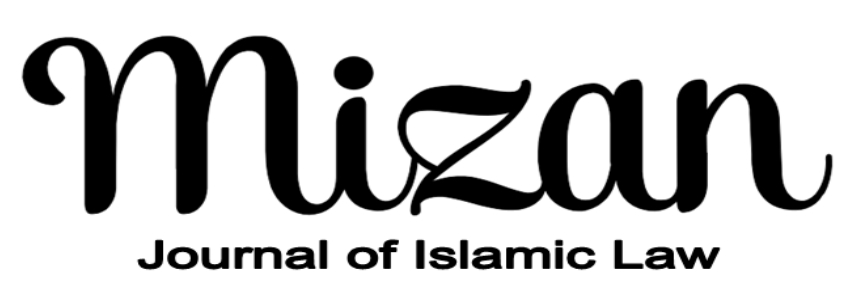

Menyambut baik kontribusi dari para ilmuwan, sarjana, profesional, dan peneliti dalam disiplin ilmu hukum untuk dipublikasi dan disebarluaskan setelah melalui mekanisme seleksi naskah, telaah mitra bebestari, dan proses penyuntingan yang ketat. 


\section{DAFTAR ISI}

1 Akses Keadilan Bagi Masyarakat Kabupaten Kepulauan

(Justice Access for the Kepulauan Seribu District Community)

Kamarusdiana

25 Efektivitas Bimbingan Perkawinan Di KUA Citeureup Dalam Menjaga Keutuhan Rumah Tangga

(Effectiveness of Marriage Guidance in KUA Citeureup in Maintaining the Integrity of Households)

Yusuf Firdaus, Kholil Nawawi, Mukhtar

37 Penerapan Asas Audi Alteram Et Partem Pada Perkara Judicial review Di Mahkamah Agung

(Implementation of the Alteram Et Partem Audi Principle On Cases of Judicial review at the Supreme Court)

Asep Syarifuddin Hidayat

51 Sistem Pelaksanaan Koperasi Mitra GBS PT. Golden Blossom Sumatera Desa Prambatan

(GBS Partner Cooperative Implementation System At PT. Golden Blossom Sumatra Prambat Village)

Saprida

71 Tinjauan Hukum Islam Tentang Asuransi

(Overview of Islamic Law About Insurance)

Abdul Wahab Abd Muhaimin

99 Perekonomian Islam Pada Masa Dinasti Fatimiyah

(Islamic Economy in the Fatimid Dynasty)

Fakhry Zamzam, Havis Aravik

117 Pemikiran Tentang Hukum Keperdataan Islam Dalam Dimensi Filsafat Ilmu (Thought about Islamic Civil Law In the Dimension of Philosophy of Science)

Abu Tamrin 



\title{
Pemikiran Tentang Hukum Keperdataan Islam Dalam Dimensi Filsafat Ilmu*
}

(Thought about Islamic Civil Law In the Dimension of Philosophy of Science)

\author{
Abu Tamrin ${ }^{1}$ \\ Program Doktor Ilmu Alquran dan Tafsir Institut PTIQ Jakarta \\ doi https://doi.org/10.32507/mizan.v3i1.433
}

\begin{abstract}
Broadly speaking, Islamic law regulates two things, namely regulating human relations with Allah in the form of worship, and regulating the relationship between one person and another, in the form of family law such as regulating relationships in household life with legal marriage and Islamic civil law. . There are characteristic differences between sharia and fiqh. Family Law Discussion, among others; Munakahat (marriage), the principles of marriage in Law Number 1 of 1974 concerning the Principles of Marriage, the principle of marriage in the Qur'an, the validity of marriage, the terms and conditions of marriage, the rights and obligations of husband and wife. Besides that, it discusses faraid (inheritance); Definition, inheritance, inheritance principles in Islam. Discussion on Islamic Civil Law: understanding of assets, assets according to experts, elements of assets, benefits of assets, transactions in Islamic Civil Law: buying and selling transactions, rent and wages (ijarah), cooperation (syirkah). The discussion of the paper concludes with a conclusion which is the answer to the formulation of the problem.
\end{abstract}

Keywords: Family Law, Civilization, Alquran

\begin{abstract}
Abstrak
Secara garis besar Hukum Islam mengatur dua hal, yaitu mengatur hubungan manusia dengan Allah Swt berupa ibadah, dan mengatur hubungan antara seseorang yang satu dengan seseorang yang lain, berupa hukum keluarga seperti pengaturan hubungan dalam hidup rumah tangga dengan perkawinan yang sah dan hukum keperdataan Islam. Ada perbedaan karakteristik antara syariah dan fiqh. Pembahasan Hukum Keluarga antara lain; Munakahat (perkawinan), prinsip-prinsip perkawinan dalam Undang-Undang Nomor 1 Tahun 1974 Tentang Pokok-pokok Perkawinan, asas perkawinan dalam Alquran, sahnya perkawinan, syarat dan rukum perkawinan, hak dan kewajiban bagi suami isteri. Disamping itu membahas faraid (kewarisan); Pengertian, kewarisan, asas-asas kewarisan dalam Islam. Pembahasan Hukum Keperdataan Islam: pengertian harta, harta menurut ahli, unsur-unsur harta, manfaat harta, transaksi dalam Hukum Keperdataan Islam: transaksi jual beli, sewa menyewa dan upah (ijarah), kerja sama (syirkah). Pembahasan makalah diakhiri dengan kesimpulan yang merupakan jawaban dari perumusan masalah.
\end{abstract}

Kata kunci: Hukum Keluarga, Keperdataan, Alquran 20 Mei 2019.

* Naskah diterima tanggal: 28 Januari 2019, direvisi: 27 Maret 2019, disetujui untuk terbit:

${ }^{1}$ Abu Tamrin adalah mahasiswa Program Doktor Ilmu al-Qur'an dan Tafsir Institut PTIQ Jakarta. Jalan Raya Pasar Jum'at Lebak Bulus No.2, Jakarta selatan. E-mail: abutamrin@uinjkt.ac.id. 


\section{Pendahuluan}

Permasalahan makalah adalah bagaiamana pengaturan Hukum Keluarga dan Hukum Keperdataan Islam? Hukum Keluarga dan Keperdataan merupakan bagian dari Hukum Islam. Istilah Hukum Islam adalah istilah yang dipergunakan di Indonesia yang dilawankan dengan Hukum Positif. Hukum Islam, yaitu seperangkat peraturan berdasarkan wahyu Allah dan /atau sunnah rasul tentang tingkah laku mukallaf yang diakui dan diyakini mengikat yang beragama Islam. ${ }^{2}$

Hukum Positif adalah hukum yang berlaku di suatu negara dibatasi oleh waktu tertentu. Pembentuk hukum positif adalah lembaga negara atau pejabat yang berwenang sesuai dengan peraturan perundang-undangan yang berlaku berupa peraturan perundang-undangan dan hukum sumber hukum formil yang lainnya. Salah satu sumber hukum pembentukan peraturan perundangundangan adalah hukum Islam, contoh pembentukan Undang-Undang Nomor 1 tahun 1974 tentang Pokok-pokok Perkawinan.

Apabila dihubungkan dengan pengertian fiqh, maka dapat dikatakan bahwa yang dimaksud dengan hukum Islam adalah yang bernama fiqh dalam literatur Islam yang berbahasa Arab. ${ }^{3}$ Istilah dalam keislaman adalah al-figh alIslam (Fiqh Islam) atau al-syariah al-Islami (syariah Islam). Pemakalah tidak menemukan dalam Alquran istilah hukum Islam. Dalam Alquran yang dipergunakan syariah Islam dijabarkan istilah, maka terdapat istilah fiqh.

Kata syariah dan derivasinya digunakan 4 kali dalam al-Qur'an, sebagai berikut:

1. QS. Al-Syura [42]:13

Dia telah mensyari'atkan bagi kamu tentang agama apa yang telah diwasiatkanNya kepada Nuh dan apa yang telah Kami wahyukan kepadamu dan apa yang telah Kami wasiatkan kepada Ibrahim, Musa dan Isa Yaitu: Tegakkanlah agama[1340] dan janganlah kamu berpecah belah tentangnya. Amat berat bagi orang-orang musyrik agama yang kamu seru mereka kepadanya. Allah menarik kepada agama itu orang yang dikehendaki-Nya dan memberi petunjuk kepada (agama)-Nya orang yang kembali (kepada-Nya).

2. QS. Al-A'raf [7]:163

Dan Tanyakanlah kepada Bani Israil tentang negeri yang terletak di dekat laut ketika mereka melanggar aturan pada hari Sabtu, di waktu datang kepada mereka ikan-ikan (yang berada di sekitar) mereka terapung-apung di permukaan air, dan di hari-hari yang bukan Sabtu, ikan-ikan itu tidak datang kepada mereka. Demikianlah Kami mencoba mereka disebabkan mereka Berlaku fasik.

2 Amir Syarifuddin, Garis-garis Besar Figh, (Jakarta: Kencana Denada Media Group, Edisi Pertama, 2003), h. 9

${ }^{3}$ Amir Syarifuddin, Garis-garis Besar Figh ..., h. 10 
3. QS. Al-Maidah [5[:148

Tetapi (sebenarnya) telah nyata bagi mereka kejahatan yang mereka dahulu selalu menyembunyikannya. Sekiranya mereka dikembalikan ke dunia, tentulah mereka kembali kepada apa yang mereka telah dilarang mengerjakannya. dan Sesungguhnya mereka itu adalah pendusta belaka.

4. QS. Al-Jasiyah [45]:18

Kemudian Kami jadikan kamu berada di atas suatu syariat (peraturan) dari urusan (agama itu), Maka ikutilah syariat itu dan janganlah kamu ikuti hawa nafsu orang-orang yang tidak mengetahui.

Secara harfiah syariah artinya jalan ke tempat mata air atau tempat yang dilalui air sungai. Penggunaannya dalam Alquran diartikan sebagai jalan yang jelas yang membawa kemenangan. Dalam terminologi ushul al-fiqh, syariah adalah titah (khitab) Allah yang berhubungan dengan perbuatan mukalaf (muslim, balig dan berakal sehat) berupa tuntunan, pilihan atau aturan (sebab, syarat atau penghalang). ${ }^{4}$ Syariah di luar akhlak. Allah telah menjadikan air sebagai penyebab kehidupan tumbuh-tumbuhan dan hewan.

Syariah dan fiqh terdapat perbedaan karakteristik. Adapun perbedaanperbedaannya yaitu:

1. Syariah diturunkan oleh Allah swt (al-Syar'i) sehingga kebenarannya bersifat mutlak (absolut), fiqh adalah formula kajian fuqaha dan kebenarannya bersifat relatif (nisbi), syariah adalah wahyu sedangkan fiqh merupakan penalaran manusia.

2. Syariah adalah satu (unity) sedang fiqh beragam (diversity).

3. Syariah bersifat otoritatif sedangkan fiqh berwatak liberal.

4. Syariah stabil atau tidak berubah sedang fiqh mengalami perubahan seiring dengan tuntutan ruang dan waktu.

5. Syariah bersifat idealistif sedangkan fiqh bercorak realistis. ${ }^{5}$

Secara garis besar hukum Islam terbagi menjadi 2 (dua): Pertama, Fiqh Ibadah meliputi aturan tentang shalat, puasa, zakat, haji dan sebagainya yang mengatur hubungan dengan Tuhannya. Kedua, Fiqh Muamalat mengatur hubungan antar manusia dengan sesamanya, seperti perikatan, sanksi hukum dan aturan lain agar terwujud ketertiban dan keadilan baik perseorangan maupun kemasyarakatan. Ada 7 rincian fiqh muamalat menurut Abdul Wahab Khalaf, antara lain sebagai berikut: ${ }^{6}$

${ }^{4}$ Abdul Wahab al-Khalaf, Ilmu Ushul al-Figh, (Jakarta: Maktabah al-Dakwah al-Islamiah Syabab al-Azhar, 1490/1990, Cet. VIII), h. 96

${ }^{5}$ Noel J. Colson, Confilic and Tension in Islamic Jureprudence, (Chicago: The University of Chicago Mess, 1969), h. 3

${ }^{6}$ Abdul Wahab al-Khalaf, Ilmu Ushul Figh..., h. 32-33 
1. Hukum keluarga, (ahwal al-syah\}siyyah) yaitu hukum yang berkaitan dengan urusan keluarga. Pembentukannya yang mengatur hubungan suami isteri dan keluarga satu dengan lainnya. Ayat Alquran yang membahas masalah ini sekitar 70 ayat.

2. Hukum sipil adalah hukum yang mengatur hubungan individu dan bentuk-bentuk hubungan seperti jual beli, sewa menyewa, utang piutang dan lain-lain agar tercipta hubungan yang harmonis dalam masyarakat. Ayat Alquranyang menjelaskan ada 70 ayat.

\section{Pembahasan}

Sesuai dengan judul makalah Hukum Keluarga dan Keperdataan Islam, maka akan dibahas lebih lanjut hukum keluarga Islam (munakahat/perkawinan, faraid/kewarisan, Hukum Keperdataan Islam (muamalat) membahas harta, transaksi dalam hukum keperdataan.

\section{Munakahat (Perkawinan)}

Perkawinan merupakan salah satu bidang fiqh, munakahat terdiri dari 2 kata yaitu nikah (نكح) dan zawaj (نواج). Kata na-ka-ha banyak terdapat dalam Alquran dengan arti kawin, salah satunya terdapat dalam QS. Al-Nisa [4]:3.7

Dan jika kamu takut tidak akan dapat Berlaku adil terhadap (hak-hak) perempuan yang yatim (bilamana kamu mengawininya), Maka kawinilah wanita-wanita (lain) yang kamu senangi : dua, tiga atau empat. kemudian jika kamu takut tidak akan dapat Berlaku adil, Maka (kawinilah) seorang saja, atau budak-budak yang kamu miliki. yang demikian itu adalah lebih dekat kepada tidak berbuat aniaya.

Begitu juga banyak terdapat kata $z a-w a-j a$ dalam Alquran dalam arti kawin. Contoh QS. Al-Ahzab[33]:37

... maka tatkala Zaid telah mengakhiri keperluan terhadap Isterinya (menceraikannya), Kami kawinkan kamu dengan dia supaya tidak ada keberatan bagi orang mukmin untuk (mengawini) isteri-isteri anak-anak angkat mereka, apabila anak-anak angkat itu telah menyelesaikan keperluannya daripada isterinya dan adalah ketetapan Allah itu pasti terjadi.

Kata nikah atau zawaj berarti "bergabung", hubungan kelamin dan juga berarti akad. Dalam terminologi kitab-kitab fiqh, nikah adalah akad atau perjanjian yang mengandung maksud membolehkan hubungan kelamin dengan menggunakan kata nakaha atau zawaja. ${ }^{8}$

Prinsip-prinsip perkawinan dalam Undang-Undang Nomor 1 Tahun

${ }^{7}$ Amir Syarifuddin, Garis-garis Besar Figh ..., h. 73

${ }^{8}$ Amir Syarifuddin, Garis-garis Besar Figh ..., h. 74 
a. Tujuan perkawinan adalah membentuk keluarga yang bahagia dan kekal. Untuk itu suami isteri perlu saling membantu dan melengkapi agar masing-masing dapat mengembangkan pribadinya, membantu dalam mencapai kesejahteraan spiritual dan material.

b. Dalam undang-undang ini dinyatakan bahwa suatu perkawinan adalah sah bilamana dilakukan menurut hukum masing-masing agamanya dan kepercayaannya itu, dan disamping itu tiap-tiap perkawinan harus dicatat menurut peraturan perundang-undangan yang belaku, pencatatan tiap-tiap perkawinan adalah sama halnya dengan pencatatan peristiwa-peristiwa penting dalam kehidupan seseorang, misalnya kelahiran, kematian yang dinyatakan dalam surat-surat keterangan, suatu akte resmi yang juga dimuat dalam daftar pencatatan.

c. Undang-undang ini menganut asas monogami, hanya apabila dikehendaki oleh yang bersangkutan, karena hukum dan agama dari yang bersangkutan mengijinkannya, seorang suami dapat beristeri lebih dari seorang. Namun demikian perkawinan seorang suami dengan lebih dari seorang isteri, meskipun hal itu dikehendaki oleh pihak-pihak yang bersangkutan hanya dapat dilakukan apabila dipenuhi berbagai persyaratan tertentu dan diputuskan oleh Pengadilan Agama.

d. Undang-undang ini mengatur prinsip, bahwa calon suami isteri itu harus siap jiwa raganya untuk dapat melangsungkan perkawinan, agar supaya dapat mewujudkan tujuan perkawinan secara baik tanpa berakhir dengan perceraian, dan mendapat keturunan yang baik dan sehat, untuk itu harus dicegah adanya perkawinan antara calon suami isteri yang masih di bawah umur, karena perkawinan itu mempunyai hubungan dengan masalah kependudukan, maka untuk mengerem lajunya kelahiran yang lebih tinggi, harus dicegah terjadinya perkawinan antara calon suami isteri yang masih di bawah umur. Sebab batas umur yang lebih rendah bagi seorang wanita untuk kawin, mengakibatkan laju kelahiran yang lebih tinggi, jika dibandingkan dengan batas umur yang lebih tinggi, berhubungan dengan itu, maka Undang-Undang Perkawinan ini menentukan batas umur untuk kawin baik bagi pria maupun bagi wanita, ialah 19 tahun bagi pria dan 16 tahun bagi wanita.

e. Karena tujuan perkawinan adalah untuk membentuk keluarga yang

9 Ahmad Rofiq, Hukum Islam di Indonesia, (Jakarta: PT. Raja Grafindo Persada, Cet. Keempat, 2000), h. 56-57 
bahagia dan kekal dan sejahtera, maka undang-undang ini menganut prinsip untuk mempersukar terjadinya perceraian. Untuk memungkinkan perceraian harus ada alasan-alasan tertentu (pasal 19 Peraturan Pemerintah Nomor 9 Tahun 1975) serta harus dilakukan di depan sidang Pengadilan Agama bagi orang Islam dan Pengadilan Negeri bagi golongan luar Islam.

f. Hak dan kedudukan isteri adalah seimbang dengan hak dan kedudukan suami baik dalam kehidupan rumah tangga maupun dalam pergaulan bermasyarakat, sehingga dengan demikian segala sesuatu dalam keluarga dapat dirundingkan dan diputuskan bersama suami isteri.

Undang-Undang Nomor 1 Tahun 1974 berasal dari Hukum Islam dan Hukum Adat. Oleh karena itu dalam Alquran terdapat penjelasan tentang asasasas yang telah pemakalah uraikan di atas. ${ }^{10}$

a. Asas membentuk keluarga yang bahagia dan kekal dan syarat calon suami isteri, QS. Al-Rum[30]:21

Dan di antara tanda-tanda kekuasaan-Nya ialah Dia menciptakan untukmu isteri-isteri dari jenismu sendiri, supaya kamu cenderung dan merasa tenteram kepadanya, dan dijadikan-Nya diantaramu rasa kasih dan sayang. Sesungguhnya pada yang demikian itu benar-benar terdapat tanda-tanda bagi kaum yang berfikir.

b. Asas monogami, QS. Al-Nisa>[4]:3

Dan jika kamu takut tidak akan dapat Berlaku adil terhadap (hak-hak) perempuan yang yatim (bilamana kamu mengawininya), Maka kawinilah wanita-wanita (lain) yang kamu senangi : dua, tiga atau empat. kemudian jika kamu takut tidak akan dapat Berlaku adil, maka (kawinilah) seorang saja, atau budak-budak yang kamu miliki. yang demikian itu adalah lebih dekat kepada tidak berbuat aniaya.

c. Asas mempersulit terjadinya perceraian, sabda Rasulullah saw, riwayat Ibn Umar:

Perbuatan halal yang paling dibenci Allah adalah talaq/perceraian (HR. Abu Daud, Ibn Majjah dan disaksikan.....)

d. Asas hak dan kedudukan suami isteri seimbang, QS. Al-Nisa[4]:32

Dan janganlah kamu iri hati terhadap apa yang dikaruniakan Allah kepada sebahagian kamu lebih banyak dari sebahagian yang lain. (karena) bagi orang laki-laki ada bahagian dari pada apa yang mereka usahakan, dan bagi Para wanita (pun) ada bahagian dari apa yang mereka usahakan, dan mohonlah kepada Allah sebagian dari karunia-Nya. Sesungguhnya Allah Maha mengetahui segala sesuatu.

${ }^{10}$ Al-San'ani, Subul al-Salam (al-Qahira: Dar Ihya al-Turas al-'Arabiy, Juz 3, 1960), h. 168 


\section{Dan QS. An-Nisa[4]:34}

Kaum laki-laki itu adalah pemimpin bagi kaum wanita, oleh karena Allah telah melebihkan sebahagian mereka (laki-laki) atas sebahagian yang lain (wanita), dan karena mereka (laki-laki) telah menafkahkan sebagian dari harta mereka. sebab itu Maka wanita yang salehah, ialah yang taat kepada Allah lagi memelihara diri ketika suaminya tidak ada, oleh karena Allah telah memelihara (mereka) wanita-wanita yang kamu khawatirkan nusyuznya, maka nasehatilah mereka dan pisahkanlah mereka di tempat tidur mereka, dan pukullah mereka. kemudian jika mereka mentaatimu, Maka janganlah kamu mencari-cari jalan untuk menyusahkannya. Sesungguhnya Allah Maha Tinggi lagi Maha besar.

Dalam perkawinan diatur tentang kafaah untuk menjaga keharmonisan rumah tangga. Ibn Mansur mendefinisikan kafaah dengan keadaan keseimbangan. Kafaah berasal dari kata asli al-kuf'u diartikan al-musawi (keseimbangan). Ketika dihubungkan dengan nikah, kafaah diartikan dengan keseimbangan antara calon suami dan isteri dari segi kedudukan (hasab), agama (din), keturunan (nasab) dan semacamnya. Dengan bahasa lain, Muhammad Abu Zahrah mendefinisikan kafaah dengan keseimbangan antara calon suami dan isteri dengan keadaan tertentu yang dengan keadaan itu mereka akan dapat menghindari kesusahan dalam mengarungi hidup rumah tangga. ${ }^{11}$

Dari paparan di atas, dapat dipahami bahwa kafaah merupakan hal yang urgen dan harus diperhatikan oleh calon suami dan isteri agar tercapai dan sukses dalam mengarungi hidup rumah tangga. ${ }^{12}$

Pasal 2 Ayat [1] Undang-Undang Nomor 1 Tahun 1974 menjelaskan bahwa: Perkawinan adalah sah, apabila dilakukan menurut hukum masingmasing agamanya dan kepercayaannya. Kalau dalam pengantin beragama Islam harus berdasarkan agama Islam oleh karena itu mencapai keluarga sakinah mawadah wa rahmah. Agar perkawinan sah menurut hukum Islam harus memenuhi syarat dan rukun sebagai berikut: ${ }^{13}$

a. Calon mempelai pria, syarat-syaratnya: Beragama Islam, Laki-laki, Jelas orangnya, Dapat memberikan persetujuan, Tidak terdapat halangan perkawinan.

b. Calon mempelai wanita, syarat-syaratnya: Beragama meskipun Yahudi atau Nasrani, Perempuan, Dapat memiliki persetujuannya, Tidak terdapat halangan perkawinan.

c. Wali nikah, syaratnya-syaratnya: Laki-laki, Dewasa, Mempunyai hak perwalian, Tidak terhalang perwaliannya.

${ }^{11}$ Jamal al-Din Muhammad bin Ibn Muharram al-Ansan al-Mansur, Lisan al-'Arabi, (Mesir: Dar al-Misriya, tth), h. 34

${ }^{12}$ Mustafa al-Siba'I, Sharh Qanun al-Ahwal al-Syahsiyyah, (Damaskus: ttp, 1385H/1967M), h. 170

${ }^{13}$ Ahmad Rofiq, Hukum Islam di Indonesia..., h. 74 
d. Saksi nikah, syarat-syaratnya: Maksimal dua orang laki-laki, Hadir dalam ijab qabul, Dapat mengerti akad, Islam, Dewasa.

e. Ijab qabul, syarat-syaratnya: Adanya pernyataan mengawinkan dari wali, Adanya pernyataan menerima dari calon mempelai pria, Memakai kata nikah, tazwij, Antara ijab dan qabul bersambung, Antara ijab dan qabul jelas maksudnya, Orang yang berkait dengan ijab dan qabul tidak sedang dalam ihram haji/umrah, Majelis ijab dan qabul itu harus dihadiri minimal 4 orang, yaitu calon mempelai pria atau wakilnya, wali dari mempelai perempuan atau wakilnya dan dua orang saksi.

Menurut pemakalah Undang-Undang Nomor 1 Tahun 1974 tidak mengenal perkawinan beda agama, hanya mengenal perkawinan beda kewarganegaraan. Pasal 2 Ayat [2] Undang-Undang Nomor 1 Tahun 1974 menjelaskan: Tiap-tiap perkawinan dicatat menurut peraturan perundangundangan yang berlaku.

Menurut penulis pencatatan perkawinan bukan syarat sahnya perkawinan, hanya bersifat administratif. Pencatatan perkawinan sebagai bukti apabila terjadi perceraian antara keduanya, terutama bagi isteri yang telah bercerai. Hal ini berkaitan dengan pembagian harta waris.

Perkawinan yang dilaksanakan sesuai ketentuan, maka timbul hak dan kewajiban suami dan isteri. Dengan melaksanakan hak dan kewajiban suami isteri, akan tercapai tujuan perkawinan membentuk keluarga sakinah mawaddah wa rahmah. Hak dan kewajiban suami isteri: ${ }^{14}$

a. Suami isteri wajib saling memperlakukan pasangannya dengan baik, tidak hanya aspek fisik, tetapi juga aspek psikis. Perlakuan baik itu secara paralel adalah kewajiban hak bagi suami dan isteri. Hal ini dijelaskan dalam QS. Al-Nisa [4]:19: ... dan bergaullah dengan mereka secara patut.

b. Suami isteri wajib saling melayani dan memuaskan kebutuhan sesamanya. Hal ini dijelaskan dalam QS. Al-Baqarah[2]:187

Dihalalkan bagi kamu pada malam hari bulan puasa bercampur dengan isteriisteri kamu; mereka adalah pakaian bagimu, dan kamupun adalah pakaian bagi mereka...

c. Suami isteri wajib saling melengkapi dan saling menjaga nama baik pasangannya. Hal ini diriwayatkan oleh Al-Baqarah[2]:187

...mereka adalah pakaian bagimu, dan kamupun adalah pakaian bagi mereka...

d. Suami isteri wajib saling melibatkan pasangannya untuk mengambil keputusan yang menyangkut kepentingan keluarga. Hal ini dipahami dari penegasan umum QS. Al-T\}ala>q[65]:6

${ }^{14}$ Mesraini, Jurnal Ilmu-ilmu Syariah dan Hukum, Vol. 10, No. 1 Maret 2008 
... dan musyawarahkanlah di antara kamu (segala sesuatu) dengan baik; dan jika kamu menemui kesulitan Maka perempuan lain boleh menyusukan (anak itu) untuknya.

e. Suami isteri wajib saling menjaga diri dan keluarganya dari kemaksiatan. Hal ini jelas diperintah dalam QS. Al-Tahrim[66]:6

“Hai orang-orang yang beriman, peliharalah dirimu dan keluargamu dari api neraka ..."

f. Suami isteri wajib saling menjaga harta masing-masing, harta bersama dan harta pasangannya. Pada dasarnya harta suami dan isteri dan menjadi milik masing-masing. Hal ini dipahami dalam QS. Al-Nisa[4]:32

“Dan janganlah kamu iri hati terhadap apa yang dikaruniakan Allah kepada sebahagian kamu lebih banyak dari sebahagian yang lain. (karena) bagi orang laki-laki ada bahagian dari pada apa yang mereka usahakan, dan bagi Para wanita (pun) ada bahagian dari apa yang mereka usahakan, dan mohonlah kepada Allah sebagian dari karunia-Nya. Sesungguhnya Allah Maha mengetahui segala sesuatu."

g. Suami isteri saling mewarisi harta peninggalan pasangannya apabila suami meninggal dunia, maka isteri berhak mendapatkan harta peninggalan suaminya. Begitu pula sebaliknya, jika isteri meninggal dunia maka suami berhak mendapatkan harta peninggalan isterinya.

h. Suami isteri sama-sama memiliki hubungan mahram dengan keluarga pasangannya. Suami haram menikahi mertuanya dan anak perempuan isterinya dan begitu juga isteri haram dinikahi oleh ayah suami dan seterusnya.

i. Apabila dari pernikahan itu memperoleh anak, maka suami isteri berhak atas anak tersebut dengan status sebagai bapak dan ibunya. Oleh karena itu suami isteri sama-sama berkewajiban mengasuh, merawat dan mendidik anak-anak mereka. Dalam QS. Al-Nisa [4]:9 dijelaskan:

“Dan hendaklah takut kepada Allah orang-orang yang seandainya meninggalkan dibelakang mereka anak-anak yang lemah, yang mereka khawatir terhadap (kesejahteraan) mereka. oleh sebab itu hendaklah mereka bertakwa kepada Allah dan hendaklah mereka mengucapkan Perkataan yang benar."

\section{Faraid (Kewarisan)}

Faraid (kewarisan) adalah salah satu bidang fiqh yang membahas peralihan hak dari orang yang meninggal dunia dan meninggalkan harta peninggalan (pewaris) kepada orang yang masih hidup (ahli waris). Harta waris yaitu harta yang beralih dari pewaris ke ahli waris. Ketentuan faraid (kewarisan) diatur dalam al-Quran. Dalam QS Al-Nisa[4]:7 dijelaskan: 
"Bagi orang laki-laki ada hak bagian dari harta peninggalan ibu-bapa dan kerabatnya, dan bagi orang wanita ada hak bagian (pula) dari harta peninggalan ibu-bapa dan kerabatnya, baik sedikit atau banyak menurut bahagian yang telah ditetapkan."

\section{QS. Al-Nisa[4]:8}

Dan apabila sewaktu pembagian itu hadir kerabat, anak yatim dan orang miskin, Maka berilah mereka dari harta itu (sekedarnya) dan ucapkanlah kepada mereka Perkataan yang baik.

\section{QS. Al-Nisa[4]:11}

Allah mensyari'atkan bagimu tentang (pembagian pusaka untuk) anak-anakmu. Yaitu : bahagian seorang anak lelaki sama dengan bahagian dua orang anak perempuan; dan jika anak itu semuanya perempuan lebih dari dua, Maka bagi mereka dua pertiga dari harta yang ditinggalkan; jika anak perempuan itu seorang saja, Maka ia memperoleh separuh harta. dan untuk dua orang ibu-bapa, bagi masing-masingnya seperenam dari harta yang ditinggalkan, jika yang meninggal itu mempunyai anak; jika orang yang meninggal tidak mempunyai anak dan ia diwarisi oleh ibu-bapanya (saja), Maka ibunya mendapat sepertiga; jika yang meninggal itu mempunyai beberapa saudara, Maka ibunya mendapat seperenam. (Pembagian-pembagian tersebut di atas) sesudah dipenuhi wasiat yang ia buat atau (dan) sesudah dibayar hutangnya. (Tentang) orang tuamu dan anak-anakmu, kamu tidak mengetahui siapa di antara mereka yang lebih dekat (banyak) manfaatnya bagimu. ini adalah ketetapan dari Allah. Sesungguhnya Allah Maha mengetahui lagi Maha Bijaksana.

\section{QS. Al-Nisa[4]:12}

Dan bagimu (suami-suami) seperdua dari harta yang ditinggalkan oleh isteriisterimu, jika mereka tidak mempunyai anak. jika isteri-isterimu itu mempunyai anak, Maka kamu mendapat seperempat dari harta yang ditinggalkannya sesudah dipenuhi wasiat yang mereka buat atau (dan) sesudah dibayar hutangnya. Para isteri memperoleh seperempat harta yang kamu tinggalkan jika kamu tidak mempunyai anak. jika kamu mempunyai anak, Maka Para isteri memperoleh seperdelapan dari harta yang kamu tinggalkan sesudah dipenuhi wasiat yang kamu buat atau (dan) sesudah dibayar hutang-hutangmu. jika seseorang mati, baik laki-laki maupun perempuan yang tidak meninggalkan ayah dan tidak meninggalkan anak, tetapi mempunyai seorang saudara laki-laki (seibu saja) atau seorang saudara perempuan (seibu saja), Maka bagi masingmasing dari kedua jenis saudara itu seperenam harta. tetapi jika saudara-saudara seibu itu lebih dari seorang, Maka mereka bersekutu dalam yang sepertiga itu, sesudah dipenuhi wasiat yang dibuat olehnya atau sesudah dibayar hutangnya dengan tidak memberi mudharat (kepada ahli waris). (Allah menetapkan yang demikian itu sebagai) syari'at yang benar-benar dari Allah, dan Allah Maha mengetahui lagi Maha Penyantun.

\section{QS. Al-Nisa[4]:33}

Bagi tiap-tiap harta peninggalan dari harta yang ditinggalkan ibu bapak dan 
karib kerabat, Kami jadikan pewaris-pewarisnya[288]. dan (jika ada) orang-orang yang kamu telah bersumpah setia dengan mereka, Maka berilah kepada mereka bahagiannya. Sesungguhnya Allah menyaksikan segala sesuatu.

\section{QS. Al-Nisa>[4]:176}

Mereka meminta fatwa kepadamu (tentang kalalah). Katakanlah: "Allah memberi fatwa kepadamu tentang kalalah (yaitu): jika seorang meninggal dunia, dan ia tidak mempunyai anak dan mempunyai saudara perempuan, Maka bagi saudaranya yang perempuan itu seperdua dari harta yang ditinggalkannya, dan saudaranya yang laki-laki mempusakai (seluruh harta saudara perempuan), jika ia tidak mempunyai anak; tetapi jika saudara perempuan itu dua orang, Maka bagi keduanya dua pertiga dari harta yang ditinggalkan oleh yang meninggal. dan jika mereka (ahli waris itu terdiri dari) saudara-saudara laki dan perempuan, Maka bahagian seorang saudara laki-laki sebanyak bahagian dua orang saudara perempuan. Allah menerangkan (hukum ini) kepadamu, supaya kamu tidak sesat. dan Allah Maha mengetahui segala sesuatu.

\section{QS. Al-Baqarah[2]:180}

Diwajibkan atas kamu, apabila seorang di antara kamu kedatangan (tanda-tanda) maut, jika ia meninggalkan harta yang banyak, Berwasiat untuk ibu-bapak dan karib kerabatnya secara ma'ruf, (ini adalah) kewajiban atas orang-orang yang bertakwa.

\section{QS. Al-Baqarah[2]:237}

Jika kamu menceraikan isteri-isterimu sebelum kamu bercampur dengan mereka, Padahal Sesungguhnya kamu sudah menentukan maharnya, Maka bayarlah seperdua dari mahar yang telah kamu tentukan itu, kecuali jika isteri-isterimu itu mema'afkan atau dima'afkan oleh orang yang memegang ikatan nikah, dan pema'afan kamu itu lebih dekat kepada takwa. dan janganlah kamu melupakan keutamaan di antara kamu. Sesungguhnya Allah Maha melihat segala apa yang kamu kerjakan.

\section{QS. Al-Baqarah[2]:240}

Dan orang-orang yang akan meninggal dunia di antara kamu dan meninggalkan isteri, hendaklah Berwasiat untuk isteri-isterinya, (yaitu) diberi nafkah hingga setahun lamanya dan tidak disuruh pindah (dari rumahnya). akan tetapi jika mereka pindah (sendiri), Maka tidak ada dosa bagimu (wali atau waris dari yang meninggal) membiarkan mereka berbuat yang ma'ruf terhadap diri mereka. dan Allah Maha Perkasa lagi Maha Bijaksana.

\section{QS. Al-Ah\}za $>$ b[33]:4}

Allah sekali-kali tidak menjadikan bagi seseorang dua buah hati dalam rongganya; dan Dia tidak menjadikan isteri-isterimu yang kamu zhihar itu sebagai ibumu, dan Dia tidak menjadikan anak-anak angkatmu sebagai anak kandungmu (sendiri). yang demikian itu hanyalah perkataan dimulutmu saja. dan Allah mengatakan yang sebenarnya dan Dia menunjukkan jalan (yang benar). 
Dalam faraid atau kewarisan dijelaskan hubungan kewarisan menurut Islam ada beberapa bentuk. ${ }^{15}$

a. Hubungan kekerabatan atau nasab atau disebut juga hubungan darah. Hubungan disini bersifat alamiah menghubungkan darah ditentukan oleh kelahiran dasar dari hubungan kekerabatan sebagai hubungan kewarisan ditentukan dalam QS. Al-Nisa[4]:7

Allah mensyari'atkan bagimu tentang (pembagian pusaka untuk) anak-anakmu. Yaitu : bahagian seorang anak lelaki sama dengan bahagian dua orang anak perempuan; dan jika anak itu semuanya perempuan lebih dari dua, Maka bagi mereka dua pertiga dari harta yang ditinggalkan; jika anak perempuan itu seorang saja, Maka ia memperoleh separo harta. dan untuk dua orang ibu-bapa, bagi masing-masingnya seperenam dari harta yang ditinggalkan, jika yang meninggal itu mempunyai anak; jika orang yang meninggal tidak mempunyai anak dan ia diwarisi oleh ibu-bapanya (saja), Maka ibunya mendapat sepertiga; jika yang meninggal itu mempunyai beberapa saudara, Maka ibunya mendapat seperenam. (Pembagian-pembagian tersebut di atas) sesudah dipenuhi wasiat yang ia buat atau (dan) sesudah dibayar hutangnya. (Tentang) orang tuamu dan anak-anakmu, kamu tidak mengetahui siapa di antara mereka yang lebih dekat (banyak) manfaatnya bagimu. ini adalah ketetapan dari Allah. Sesungguhnya Allah Maha mengetahui lagi Maha Bijaksana.

b. Hubungan perkawinan. Apabila seorang laki-laki telah melangsungkan akad nikah yang sah dengan seorang perempuan, maka diantara keduanya telah terdapat hubungan kewarisan, dalam arti isteri menjadi ahli waris bagi suaminya yang telah meninggal dunia dan suami menjadi ahli waris bagi isteri yang telah meninggal dunia. Dasar hukum adanya hubungan kewarisan antara suami dan isteri adalah QS. Al-Nisa[4]:33

“Bagi tiap-tiap harta peninggalan dari harta yang ditinggalkan ibu bapak dan karib kerabat, Kami jadikan pewaris-pewarisnya[288]. dan (jika ada) orang-orang yang kamu telah bersumpah setia dengan mereka, Maka berilah kepada mereka bahagiannya. Sesungguhnya Allah menyaksikan segala sesuatu." Islam: ${ }^{16}$

Adapun rukun dan syarat. Berikut ini dijelaskan asas-asas kewarisan

\section{a. Asas ijbari}

Yang dimaksud asas ijbari yaitu pengalihan harta dari seseorang yang meninggal dunia kepada ahli warisnya berlaku dengan sendirinya menurut ketetapan Allah swt tanpa digantungkan kepada kehendak pewaris atau ahli waris.

Asas ijbari hukum kewarisan Islam dapat dilihat dari beberapa segi

${ }^{15}$ Amir Syarifuddin, Garis-garis Besar Figh ..., h. 149-150

16 Zainuddin Ali, Hukum Perdata Islam di Indonesia, (Jakarta: Sinar Grafika,tth), Cet. Keempat, h. 121-125 
yaitu:

1) Dari pengalihan harta yang pasti terjadi setelah orang meninggal dunia. Hal ini dapat dilihat dalam QS. Al-Nisa[4]:7

Bagi orang laki-laki ada hak bagian dari harta peninggalan ibu-bapa dan kerabatnya, dan bagi orang wanita ada hak bagian (pula) dari harta peninggalan ibu-bapa dan kerabatnya, baik sedikit atau banyak menurut bahagian yang telah ditetapkan.

2) Harta yang sudah ditentukan bagi masing-masing ahli waris. Hal ini tercermin dalam harta mafruda yang makna asalnya adalah ditentukan atau diperhitungkan apa yang sudah ditentukan atau diperhitungkan oleh Allah swt waijb dilaksanakan oleh hamba-hambaNya.

3) Kepastian menerima harta peninggalan yakni mereka yang mempunyai hubungan kekerabatan dan ikatan perkawinan dengan pewaris dirinci oleh Allah swt dalam beberapa surat al-Qur'an: QS. Al-Nisa[4]:1

Hai sekalian manusia, bertakwalah kepada Tuhan-mu yang telah menciptakan kamu dari seorang diri, dan dari padanya Allah menciptakan isterinya; dan dari pada keduanya Allah memperkembang biakkan laki-laki dan perempuan yang banyak. dan bertakwalah kepada Allah yang dengan (mempergunakan) namaNya kamu saling meminta satu sama lain dan (peliharalah) hubungan silaturrahim. Sesungguhnya Allah selalu menjaga dan mengawasi kamu.

QS. Al-Nisa[4]:2

Dan berikanlah kepada anak-anak yatim (yang sudah balig) harta mereka, jangan kamu menukar yang baik dengan yang buruk dan jangan kamu Makan harta mereka bersama hartamu. Sesungguhnya tindakan-tindakan (menukar dan memakan) itu, adalah dosa yang besar.

QS. Al-Nisa[4]:33

Bagi tiap-tiap harta peninggalan dari harta yang ditinggalkan ibu bapak dan karib kerabat, Kami jadikan pewaris-pewarisnya dan (jika ada) orang-orang yang kamu telah bersumpah setia dengan mereka, Maka berilah kepada mereka bahagiannya. Sesungguhnya Allah menyaksikan segala sesuatu.

QS. Al-Nisa[4]:176

Mereka meminta fatwa kepadamu (tentang kalalah). Katakanlah: "Allah memberi fatwa kepadamu tentang kalalah (yaitu): jika seorang meninggal dunia, dan ia tidak mempunyai anak dan mempunyai saudara perempuan, Maka bagi saudaranya yang perempuan itu seperdua dari harta yang ditinggalkannya, dan saudaranya yang laki-laki mempusakai (seluruh harta saudara perempuan), jika ia tidak mempunyai anak; tetapi jika saudara perempuan itu dua orang, Maka bagi keduanya dua pertiga dari harta yang ditinggalkan oleh yang meninggal. dan jika mereka (ahli waris itu terdiri dari) saudara-saudara laki dan perempuan, Maka bahagian seorang saudara laki-laki sebanyak bahagian dua orang saudara perempuan. Allah menerangkan (hukum ini) kepadamu, supaya kamu tidak 
sesat. dan Allah Maha mengetahui segala sesuatu.

Rincian ahli waris dan pembagiannya yang sudah pasti itu tidak ada kekuasaan manapun yang dapat mengubahnya.

b. Asas Bilateral

Asas bilateral dalam hukum kewarisan Islam, yaitu seseorang menerima hak atau bagian warisan dari kedua belah pihak, dari kerabat keturunan laki-laki dan dari kerabat keturunan perempuan. Asas bilateral mempunyai 2 dimensi saling mewarisi. Dalam Alquran dijelaskan: QS. Al-Nisa[4]:7

Bagi orang laki-laki ada hak bagian dari harta peninggalan ibu-bapa dan kerabatnya, dan bagi orang wanita ada hak bagian (pula) dari harta peninggalan ibu-bapa dan kerabatnya, baik sedikit atau banyak menurut bahagian yang telah ditetapkan.

QS. Al-Nisa[4]:12

Dan bagimu (suami-suami) seperdua dari harta yang ditinggalkan oleh isteriisterimu, jika mereka tidak mempunyai anak. jika isteri-isterimu itu mempunyai anak, Maka kamu mendapat seperempat dari harta yang ditinggalkannya sesudah dipenuhi wasiat yang mereka buat atau (dan) sesudah dibayar hutangnya. Para isteri memperoleh seperempat harta yang kamu tinggalkan jika kamu tidak mempunyai anak. jika kamu mempunyai anak, Maka Para isteri memperoleh seperdelapan dari harta yang kamu tinggalkan sesudah dipenuhi wasiat yang kamu buat atau (dan) sesudah dibayar hutang-hutangmu. jika seseorang mati, baik laki-laki maupun perempuan yang tidak meninggalkan ayah dan tidak meninggalkan anak, tetapi mempunyai seorang saudara laki-laki (seibu saja) atau seorang saudara perempuan (seibu saja), Maka bagi masingmasing dari kedua jenis saudara itu seperenam harta. tetapi jika saudara-saudara seibu itu lebih dari seorang, Maka mereka bersekutu dalam yang sepertiga itu, sesudah dipenuhi wasiat yang dibuat olehnya atau sesudah dibayar hutangnya dengan tidak memberi mudharat (kepada ahli waris). (Allah menetapkan yang demikian itu sebagai) syari'at yang benar-benar dari Allah, dan Allah Maha mengetahui lagi Maha Penyantun.

QS. Al-Nisa[4]:176

Mereka meminta fatwa kepadamu (tentang kalalah). Katakanlah: "Allah memberi fatwa kepadamu tentang kalalah (yaitu): jika seorang meninggal dunia, dan ia tidak mempunyai anak dan mempunyai saudara perempuan, Maka bagi saudaranya yang perempuan itu seperdua dari harta yang ditinggalkannya, dan saudaranya yang laki-laki mempusakai (seluruh harta saudara perempuan), jika ia tidak mempunyai anak; tetapi jika saudara perempuan itu dua orang, Maka bagi keduanya dua pertiga dari harta yang ditinggalkan oleh yang meninggal. dan jika mereka (ahli waris itu terdiri dari) saudara-saudara laki dan perempuan, Maka bahagian seorang saudara laki-laki sebanyak bahagian dua orang saudara perempuan. Allah menerangkan (hukum ini) kepadamu, supaya kamu tidak sesat. dan Allah Maha mengetahui segala sesuatu. 
c. Asas Individual

Asas individual dalam hukum kewarisan Islam yaitu harta warisan dapat dibagi-bagi kepada ahli waris untuk dimiliki secara perorangan. Untuk itu dalam pelaksanaannya seluruh harta warisan dinyatakan dalam nilai tertentu yang kemudian dibagikan kepada setiap ahli waris yang berhak menerimanya menurut kadar bagian masing-masing.

Asas individual dalam hukum Islam dijelaskan dalam beberapa surat alQur'an: QS. Al-Nisa[4]:7

Bagi orang laki-laki ada hak bagian dari harta peninggalan ibu-bapa dan kerabatnya, dan bagi orang wanita ada hak bagian (pula) dari harta peninggalan ibu-bapa dan kerabatnya, baik sedikit atau banyak menurut bahagian yang telah ditetapkan.

\section{QS. Al-Nisa [4]:11}

Allah mensyari'atkan bagimu tentang (pembagian pusaka untuk) anak-anakmu. Yaitu : bahagian seorang anak lelaki sama dengan bahagian dua orang anak perempuan; dan jika anak itu semuanya perempuan lebih dari dua, Maka bagi mereka dua pertiga dari harta yang ditinggalkan; jika anak perempuan itu seorang saja, Maka ia memperoleh separuh harta. dan untuk dua orang ibu-bapa, bagi masing-masingnya seperenam dari harta yang ditinggalkan, jika yang meninggal itu mempunyai anak; jika orang yang meninggal tidak mempunyai anak dan ia diwarisi oleh ibu-bapanya (saja), Maka ibunya mendapat sepertiga; jika yang meninggal itu mempunyai beberapa saudara, Maka ibunya mendapat seperenam. (Pembagian-pembagian tersebut di atas) sesudah dipenuhi wasiat yang ia buat atau (dan) sesudah dibayar hutangnya. (Tentang) orang tuamu dan anak-anakmu, kamu tidak mengetahui siapa di antara mereka yang lebih dekat (banyak) manfaatnya bagimu. ini adalah ketetapan dari Allah. Sesungguhnya Allah Maha mengetahui lagi Maha Bijaksana.

QS. Al-Nisa[4]:12

Dan bagimu (suami-suami) seperdua dari harta yang ditinggalkan oleh isteriisterimu, jika mereka tidak mempunyai anak. jika isteri-isterimu itu mempunyai anak, Maka kamu mendapat seperempat dari harta yang ditinggalkannya sesudah dipenuhi wasiat yang mereka buat atau (dan) sesudah dibayar hutangnya. Para isteri memperoleh seperempat harta yang kamu tinggalkan jika kamu tidak mempunyai anak. jika kamu mempunyai anak, Maka Para isteri memperoleh seperdelapan dari harta yang kamu tinggalkan sesudah dipenuhi wasiat yang kamu buat atau (dan) sesudah dibayar hutang-hutangmu. jika seseorang mati, baik laki-laki maupun perempuan yang tidak meninggalkan ayah dan tidak meninggalkan anak, tetapi mempunyai seorang saudara laki-laki (seibu saja) atau seorang saudara perempuan (seibu saja), Maka bagi masingmasing dari kedua jenis saudara itu seperenam harta. tetapi jika saudara-saudara seibu itu lebih dari seorang, Maka mereka bersekutu dalam yang sepertiga itu, sesudah dipenuhi wasiat yang dibuat olehnya atau sesudah dibayar hutangnya dengan tidak memberi mudharat (kepada ahli waris). (Allah menetapkan yang 
demikian itu sebagai) syari'at yang benar-benar dari Allah, dan Allah Maha mengetahui lagi Maha Penyantun.

QS. Al-Nisa[4]:176

Mereka meminta fatwa kepadamu (tentang kalalah). Katakanlah: "Allah memberi fatwa kepadamu tentang kalalah (yaitu): jika seorang meninggal dunia, dan ia tidak mempunyai anak dan mempunyai saudara perempuan, Maka bagi saudaranya yang perempuan itu seperdua dari harta yang ditinggalkannya, dan saudaranya yang laki-laki mempusakai (seluruh harta saudara perempuan), jika ia tidak mempunyai anak; tetapi jika saudara perempuan itu dua orang, Maka bagi keduanya dua pertiga dari harta yang ditinggalkan oleh yang meninggal. dan jika mereka (ahli waris itu terdiri dari) saudara-saudara laki dan perempuan, Maka bahagian seorang saudara laki-laki sebanyak bahagian dua orang saudara perempuan. Allah menerangkan (hukum ini) kepadamu, supaya kamu tidak sesat. dan Allah Maha mengetahui segala sesuatu.

d. Asas Keadilan Berimbang

Asas keadilan berimbang dalam hukum kewarisan Islam berarti keseimbangan antara hak yang diperoleh dengan keperluan dan kegunaan dalam melaksanakan kewajiban.

Asas keadilan keseimbangan antara hak yang diperoleh sesorang dengan kewajiban yang harus ditunaikannya contoh anak laki-laki dan perempuan mendapat hak yang sebanding dengan kewajiban yang dipikulnya masingmasing dalam kehidupan keluarga dan masyarakat.

Dalam hukum kewarisan Islam harta peninggalan yang diterima oleh ahli waris dari pewaris pada hakikatnya adalah kelanjutan tanggung jawab pewaris terhadap keluarganya oleh karna itu bagian yang diterima oleh masing-masing ahli waris berimbang dengan kewajiban atau tanggung jawab terhadap keluarganya. QS. Al-Thalaq[65]:7

Hendaklah orang yang mampu memberi nafkah menurut kemampuannya. dan orang yang disempitkan rezkinya hendaklah memberi nafkah dari harta yang diberikan Allah kepadanya. Allah tidak memikulkan beban kepada seseorang melainkan sekedar apa yang Allah berikan kepadanya. Allah kelak akan memberikan kelapangan sesudah kesempitan.

\section{QS. Al-Baqarah[2]:177}

Bukanlah menghadapkan wajahmu ke arah timur dan barat itu suatu kebajikan, akan tetapi Sesungguhnya kebajikan itu ialah beriman kepada Allah, hari Kemudian, malaikat-malaikat, kitab-kitab, nabi-nabi dan memberikan harta yang dicintainya kepada kerabatnya, anak-anak yatim, orang-orang miskin, musafir (yang memerlukan pertolongan) dan orang-orang yang meminta-minta; dan (memerdekakan) hamba sahaya, mendirikan shalat, dan menunaikan zakat; dan orang-orang yang menepati janjinya apabila ia berjanji, dan orang-orang yang sabar dalam kesempitan, penderitaan dan dalam peperangan. mereka Itulah orang-orang yang benar (imannya); dan mereka Itulah orang-orang yang 
bertakwa.

e. Asas akibat kematian

Asas akibat kematian dalam hukum kewarisan Islam berarti kewarisan ada kalau ada yang meninggal dunia dan meninggalkan harta waris. Pengalihan harta seseorang kepada orang lain terjadi setelah orang yang mempunyai harta itu meninggal dunia. Ini berarti harta seseorang tidak dapat beralih kepada orang lain selama orang yang mempunyai harta itu masih hidup.

Asas akibat kematian seseorang mempunyai kaitan dengan asas ijbari yang sudah disebutkan yakni seseorang tidak sekehendaknya saja menentukan penggunaan hartanya setelah ia meninggal dunia. Melalui wasiat menurut hukum kewarisan Islam dalam batas-batas menentukan seperempat harta kekayaan setelah ia meninggal dunia, tetapi wasiat itu merupakan ketentuan tersendiri terpisah dari ketentuan hukum kewarisan Islam.

\section{Harta}

\section{a. Pengertian Harta}

Harta secara sederhana mengandung arti sesuatu yang dapat dimiliki. Ia termasuk salah satu sendi bagi kehidupan manusia di dunia, karena tanpa harta atau secara khusus adalah makanan manusia tidak akan dapat bertahan oleh karena itu Allah swt menyuruh manusia memperolehnya, memilikinya dan memanfaatkannya bagi kehidupan manusia dan Allah swt melarang berbuat sesuatu yang akan merusak dan meniadakan harta itu. Ia dapat berupa materi dan immateri. Harta dalam bentuk materi bergerak dan ada yang tidak bergerak, sedang harta dalam bentuk immateri berupa hak-hak. ${ }^{17}$

Dalam hukum perdata Islam, bahwa hakikat kepemilikan adalah Allah swt. Hal ini dijelaskan dalam al-Qur'an, antara lain:

QS. Al-Maidah[5]:17:

Sesungguhnya telah kafirlah orang-orang yang berkata: "Sesungguhnya Allah itu ialah Al masih putera Maryam". Katakanlah: "Maka siapakah (gerangan) yang dapat menghalang-halangi kehendak Allah, jika Dia hendak membinasakan Al masih putera Maryam itu beserta ibunya dan seluruh orang-orang yang berada di bumi kesemuanya?". kepunyaan Allahlah kerajaan langit dan bumi dan apa yang ada diantara keduanya; Dia menciptakan apa yang dikehendaki-Nya. dan Allah Maha Kuasa atas segala sesuatu.

QS. Ali Imran[3]:104

Dan hendaklah ada di antara kamu segolongan umat yang menyeru kepada kebajikan, menyuruh kepada yang ma'ruf dan mencegah dari yang munkar;

${ }_{17}$ Amir Syarifuddin, Garis-garis Besar Figh..., h. 177 
merekalah orang-orang yang beruntung.

QS. Al-Maidah[5]:17

Hai orang-orang yang beriman, penuhilah aqad-aqad itu. Dihalalkan bagimu binatang ternak, kecuali yang akan dibacakan kepadamu. (yang demikian itu) dengan tidak menghalalkan berburu ketika kamu sedang mengerjakan haji. Sesungguhnya Allah menetapkan hukum-hukum menurut yang dikehendakiNya.

Berdasarkan penjelasan surat Alquran di atas dapat dipahami bahwa hakekat harta adalah Allah swt, namun seluruh yang dimiliki oleh Allah swt dijadikan Allah swt untuk manusia semuanya sebagaimana dinyatakan dalam ${ }^{18}$ QS. Al-Baqarah[2]:29

Dia-lah Allah, yang menjadikan segala yang ada di bumi untuk kamu dan Dia berkehendak (menciptakan) langit, lalu dijadikan-Nya tujuh langit. dan Dia Maha mengetahui segala sesuatu.

QS. Al-Jumuah[62]:10

Apabila telah ditunaikan shalat, Maka bertebaranlah kamu di muka bumi; dan carilah karunia Allah dan ingatlah Allah banyak-banyak supaya kamu beruntung.

Menurut TM. Hasbi Ash-Shiddiqy, yang disebut harta adalah: ${ }^{19}$

a. Nama selain manusia yang diciptakan Allah swt untuk memenuhi kebutuhan hidup manusia dapat dipelihara pada suatu tempat dan dikelola (tasaruf) dengan jalan ikhtiar.

b. Sesuatu yang dapat dimiliki oleh setiap manusia, baik oleh seluruh manusia maupun oleh sebagian manusia.

c. Sesuatu yang dapat dimiliki dan mempunyai nilai harga seperti sebiji beras dapat dimiliki oleh manusia, dapat diambil kegunaannya dan dapat disimpan.

d. Sesuatu yang berwujud sesuatu yang tidak berwujud meskipun dapat diambil manfaatnya tidak termasuk harta misalnya manfaat, karena manfaat tidak berwujud sehingga tidak termasuk harta.

e. Sesuatu yang dapat disimpan dalam waktu yang lama atau sebentar dan dapat diambil manfaatnya ketika dibutuhkan.

TM. Hasbi Ash-Shiddieqy memberi definisi yang banyak. Berbeda Hanafiah yang menjelaskan yang dimaksud harta berupa sesuatu yang berwujud (a'yun). Berikut pemakalah paparkan. Yang dimaksud harta menurut sebagian

18 Amir Syarifuddin, Garis-garis Besar Figh..., h. 178

19 TM. Hasbi Ash-Shiddieqy, Pengantar Ilmu Muamalat, (Jakarta: PT. Bulan Bintang, 1984), h. 40 
ulama lainnya. ${ }^{20}$ Menurut sebagian ulama, yang dimaksud harta ialah: "Sesuatu yang diinginkan manusia berdasarkan tabiatnya baik manusia itu akan memberikan atau akan menyimpannya."Menurut sebagian ulama lainnya, bahwa yang dimaksud harta ialah: Segala zat (ain) yang berharga bersifat materi yang berputar di antara manusia. Dari pendapat pakar maupun sebagian ulama dan sebagian lainnya berbeda pendapat menghasilkan apa yang dinamakan harta.

\section{b. Unsur-unsur Harta}

Menurut para fuqaha harta bersendi pada 2 unsur, yaitu unsur ainiyah dan unsur urf. Unsur ainiyah ialah bahwa harta itu ada wujudnya dalam kenyataan (a'yun). Manfaat sebuah rumah yang dipelihara manusia tidak disebut harta, tetapi termasuk mulhak atau hak. Unsur urf ialah segala sesuatu yang dipandang harta oleh sekelompok manusia atau sebagian manusia tidaklah manusia memelihara sesuatu kecuali menginginkan manfaatnya baik manfaat lahiriah maupun manfaat ma'nawiyah. ${ }^{21}$

\section{c. Pemanfaatan Harta}

Apabila harta yang diperoleh sesuai dengan ketentuan Allah swt, maka harta yang telah diperoleh dengan mempergunakan ketentuan Allah swt, maka harus dipergunakan sesuai dengan ketentuan Allah swt. Tujuan utama dari harta dijelaskan oleh Allah swt untuk menanggung kehidupan manusia. Oleh karena itu harta harus digunakan untuk maksud tersebut. Berikut ini dipaparkan petunjuk Allah swt sebagai berikut:22

1) Digunakan untuk kepentingan hidup sendiri penggunaan harta untuk kebutuhan hidup dinyatakan Allah dalam firmanNya pada beberapa ayat Alquran di antaranya:

QS. Al-Mursalat[77]:43: (Dikatakan kepada mereka): "Makan dan minumlah kamu dengan enak karena apa yang telah kamu kerjakan".

QS. Al-A'raf [7]:31

Hai anak Adam, pakailah pakaianmu yang indah di Setiap (memasuki) mesjid, Makan dan minumlah, dan janganlah berlebih-lebihan. Sesungguhnya Allah tidak menyukai orang-orang yang berlebih-lebihan.

QS. Al-Isra[17]:26

Dan berikanlah kepada keluarga-keluarga yang dekat akan haknya, kepada orang miskin dan orang yang dalam perjalanan dan janganlah kamu menghambur-hamburkan (hartamu) secara boros.

${ }^{20}$ Hendi Suhendi, Fiqh Muamalah, (Jakarta: PT. Raja Grafindo Persada, 2002), h. 10

${ }^{21}$ Hendi Suhendi, Fiqh Muamalah..., h. 11-12

${ }^{22}$ Amir Syarifuddin, Garis-garis Fiqh..., h. 


\section{QS. Al-Isra[17]:77}

(Kami menetapkan yang demikian) sebagai suatu ketetapan terhadap Rasul-rasul Kami yang Kami utus sebelum kamu dan tidak akan kamu dapati perubahan bagi ketetapan Kami itu.

2) Digunakan untuk memenuhi kewajiban kepada Allah. Kewajiban kepada Allah swt itu ada 3 macam, yaitu:

a) Kewajiban materi yang berkenaan dengan kewajiban agama yang merupakan hutang terhadap Allah; untuk keperluan membayar zakat atau nazar atau kewajiban materi lainnya, meskipun secara praktis juga digunakan dan dimanfaatkan untuk manusia. Hal ini dijelaskan dalam QS. Al-Baqarah[2]:267

"Hai orang-orang yang beriman, nafkahkanlah (di jalan Allah) sebagian dari hasil usahamu yang baik-baik dan sebagian dari apa yang Kami keluarkan dari bumi untuk kamu. dan janganlah kamu memilih yang buruk-buruk lalu kamu menafkahkan daripadanya, Padahal kamu sendiri tidak mau mengambilnya melainkan dengan memicingkan mata terhadapnya. dan ketahuilah, bahwa Allah Maha Kaya lagi Maha Terpuji."

b) Kewajiban materi yang harus ditunaikan untuk keluarga yaitu isteri, anak dan kerabat. Hal ini dijelaskan dalam QS. Al-Baqarah[2]:233

Para ibu hendaklah menyusukan anak-anaknya selama dua tahun penuh, Yaitu bagi yang ingin menyempurnakan penyusuan. dan kewajiban ayah memberi Makan dan pakaian kepada Para ibu dengan cara ma'ruf. seseorang tidak dibebani melainkan menurut kadar kesanggupannya. janganlah seorang ibu menderita kesengsaraan karena anaknya dan seorang ayah karena anaknya, dan warispun berkewajiban demikian. apabila keduanya ingin menyapih (sebelum dua tahun) dengan kerelaan keduanya dan permusyawaratan, Maka tidak ada dosa atas keduanya. dan jika kamu ingin anakmu disusukan oleh orang lain, Maka tidak ada dosa bagimu apabila kamu memberikan pembayaran menurut yang patut. bertakwalah kamu kepada Allah dan ketahuilah bahwa Allah Maha melihat apa yang kamu kerjakan.

c) Dimanfaatkan bagi kepentingan sosial. Perolehan rejeki antara seseorang dengan seseorang yang lain tidak sama. Perbedaan perolehan rejeki dinyatakan dalam firman Allah QS. Al-Nah 1[16]:71

“Dan Allah melebihkan sebahagian kamu dari sebagian yang lain dalam hal rezki, tetapi orang-orang yang dilebihkan (rezkinya itu) tidak mau memberikan rezki mereka kepada budak-budak yang mereka miliki, agar mereka sama (merasakan) rezki itu. Maka mengapa mereka mengingkari nikmat Allah?"

QS. Al-Munafiqun[63]:10

Dan belanjakanlah sebagian dari apa yang telah Kami berikan kepadamu 
sebelum datang kematian kepada salah seorang di antara kamu; lalu ia berkata: "Ya Rabb-ku, mengapa Engkau tidak menangguhkan (kematian)ku sampai waktu yang dekat, yang menyebabkan aku dapat bersedekah dan aku Termasuk orang-orang yang saleh?"

\section{Kesimpulan}

Untuk menjawab perumusan masalah, maka pemakalah dapat menarik kesimpulan sebagai berikut:

1. Perkawinan merupakan bagian dari hukum keluarga.

2. Untuk menjaga keharmonisan keluarga dan untuk mencapai sukses dalam hidup berumah tangga penting memperhatikan kekufuan dari suami dan isteri.

3. Sahnya perkawinan ditentukan menurut hukum agama dan kepercayaan masing-masing. Pencatatan hanya bersifat administratif.

4. Dalam Alquran banyak ayat yang menjelaskan tentang faraid (kewarisan).

5. Harta merupakan hal yang penting dalam kehidupan manusia.

6. Penggunaan harta untuk kepentingan kehidupan manusia dan untuk memenuhi kewajiban kepada Allah swt.

7. Transaksi dalam hukum keperdataan Islam jumlahnya banyak antara lain jual beli, sewa menyewa dan upah (ijarah dan kerja sama (syirkah).

8. Pengaturan buku III KUH Perdata terbuka. Oleh karena itu ada asas kebebasan berkontrak.

9. Syarat sah perjanjian terdapat dalam pasal $1320 \mathrm{KUH}$ Perdata.

\section{Daftar Pustaka}

Ahmad, Idris. Figh al-Syar'iyyah, Jakarta: Karya Indah, 1986.

Aji, Ahmad Mukri. Kontekstualisasi Ijtihad Dalam Diskursus Pemikiran Hukum Islam di Indonesia, Bogor: Pustaka Pena Ilahi, 2010.

Aji, Ahmad Mukri. Rasionalitas ijtihad Ibn Rusyd: kajian atas figh jinayat dalam kitab "Bidayat al-Mujtahid wa Nihayat al-Muqtashid, Bogor: Pustaka Pena Ilahi, 2010. 
Aji, Ahmad Mukri. Urgensi Maslahat Mursalah Dalam Dialektika Pemikiran Hukum Islam, Bogor: Pustaka Pena Ilahi, 2012.

Ali, Zainuddin. Hukum Perdata Islam di Indonesia, Jakarta: Sinar Grafika,tth), Cet. Keempat.

Al-Khalaf, Abdul Wahab. Ilmu Ushul al-Figh, Jakarta: Maktabah al-Dakwah alIslamiah Syabab al-Azhar, 1490/1990, Cet. VIII.

Al-Mansur, Jamal al-Din Muhammad bin Ibn Muharram al-Ansan. Lisan al'Arabi, Mesir: Dar al-Misriya, tth.

Al-San'ani, Subul al-Salam, al-Qa>hira: Da>r Ih\}ya> al-Turas al-'Arabiy, Juz 3, 1960.

Ash-Shiddieqy, TM. Hasbi. Pengantar Ilmu Muamalat, Jakarta: PT. Bulan Bintang, 1984.

Aji, Ahmad Mukri; Yunus, Nur Rohim. Basic Theory of Law and Justice, Jakarta: Jurisprudence Institute, 2018.

Colson, Noel J. Confilic and Tension in Islamic Jureprudence, Chicago: The University of Chicago Mess, 1969.

Maggalatung, A Salman. "Hubungan Antara Fakta Norma, Moral, Dan Doktrin Hukum Dalam Pertimbangan Putusan Hakim," dalam Jurnal Cita Hukum, Vol. 2, No. 2 (2014).

Mesraini, Jurnal Ilmu-ilmu Syariah dan Hukum, Vol. 10, No. 1 Maret 2008

Mustafa al-Siba'I, Sharh Qanun al-Ahwal al-Syahsiyyah, Damaskus: ttp, 1385H/1967M.

Rofiq, Ahmad. Hukum Islam di Indonesia, Jakarta: PT. Raja Grafindo Persada, Cet. Keempat, 2000.

Sabiq, Sayyid. Fiqh Sunnah, Beirut: Dar al-Fikr, 1977.

Soeharnoko, Hukum Perjanjian, Teori dan Analisa Kasus, Jakarta: Prenada Media, 2004

Suhendi, Hendi. Figh Muamalah, Jakarta: PT. Raja Grafindo Persada, 2002

Syarifuddin, Amir. Garis-garis Besar Figh, Jakarta: Kencana Denada Media Group, Edisi Pertama, 2003.

Triwulan, Titik. Hukum Perdata dalam Sistem Hukum Nasional, Jakarta: Kencana, 2008.

Undang-Undang Nomor 1 Tahun 1974 Tentang Pokok-Pokok Perkawinan 


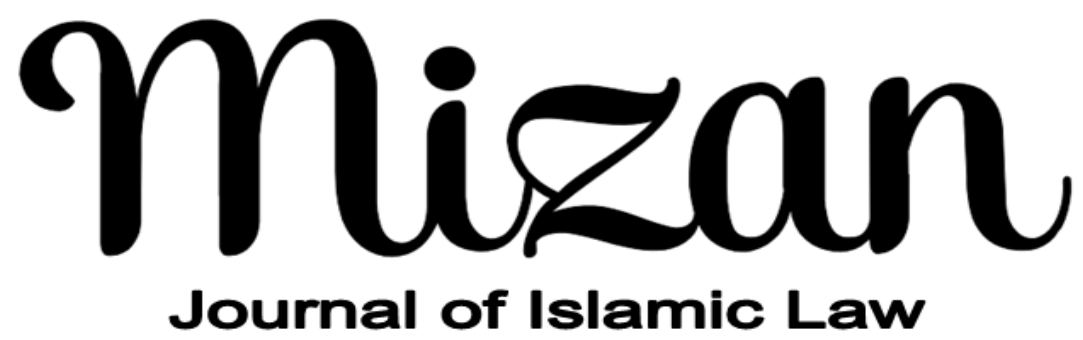

\section{PEDOMAN TEKNIS PENULISAN BERKALA ILMIAH}

1. Artikel adalah benar-benar karya asli penulis, tidak mengandung unsur plagiasi, dan belum pernah dipublikasikan dan/atau sedang dalam proses publikasi pada media lain yang dinyatakan dengan surat pernyataan yang ditandatangani di atas meterai Rp 6000;

2. Naskah dapat berupa konseptual, resume hasil penelitian, atau pemikiran tokoh;

3. Naskah dapat berbahasa Indonesia, Inggris, Arab, maupun bahasa Rusia;

4. Naskah harus memuat informasi keilmuan dalam ranah ilmu hukum Positif;

5. Aturan penulisan adalah sebagai berikut:

a. Judul. Ditulis dengan huruf kapital, maksimum 12 kata diposisikan di tengah (centered);

b. Nama penulis. Ditulis utuh, tanpa gelar, disertai afiliasi kelembagaan dengan alamat lengkap, dan alamat e-mail;

c. Abstrak. Ditulis dalam bahasa Inggris dan Bahasa Indonesia antara 80-120 kata;

d. Sistematika penulisan naskah adalah sebagai berikut:

1) Judul;

2) Nama penulis (tanpa gelar akademik), nama dan alamat afiliasi penulis, dan e-mail;

3) Abstrak ditulis dalam dua bahasa, yaitu bahasa Indonesia dan Inggris, antara 80-120 kata;

4) Kata-kata kunci, antara 2-5 konsep yang mencerminkan substansi artikel;

5) Pendahuluan;

6) Sub judul (sesuai dengan keperluan pembahasan);

7) Penutup; dan

8) Pustaka Acuan (hanya memuat sumber-sumber yang dirujuk dan sedapat mungkin terbitan 10 tahun terakhir).

e. Ukuran kertas yang digunakan adalah kertas HVS 70 gram, ukuran A4, margin: atas $3,5 \mathrm{~cm}$, bawah $3.5 \mathrm{~cm}$, kiri $3,5 \mathrm{~cm}$, dan kanan $3,5 \mathrm{~cm}$;

f. Panjang Naskah antara 13 s.d. 15 halaman, spasi 1, huruf Palatino, ukuran 11;

g. Pengutipan kalimat. Kutipan kalimat ditulis secara langsung apabila lebih dari empat baris dipisahkan dari teks dengan jarak satu spasi dengan ukuran huruf 10 point. Sedangkan kutipan kurang dari empat baris diintegrasikan dalam teks, dengan tanda apostrof ganda di awal dan di akhir kutipan. Setiap kutipan diberi nomor. Sistem pengutipan adalah footnote (bukan bodynote atau endnote). Penulisan footnote menggunakan sistem turabian. Setiap artikel, buku, dan sumber lainnya yang dikutip harus tercantum dalam pustaka acuan;

$h$. Pengutipan Ayat Alquran dan Hadis. Ayat yang dikutip menyertakan keterangan ayat dalam kurung, dengan menyebut nama surah, nomor surah, dan nomor ayat, seperti (Q.s. al-Mu'min [40]: 43). Pengutipan Hadis menyebutkan nama perawi (H.r. al-Bukhārĩ dan Muslim) ditambah referensi versi cetak kitab Hadis yang dikutip. Hadis harus dikutip dari kitab-kitab Hadis standar (Kutub al-Tis'ah);

i. Cara pembuatan footnote. Footnote ditulis dengan font Palation size 9, untuk pelbagai sumber, antara lain: 
1) Buku: nama utuh penulis (tanpa gelar), judul buku (tempat terbit: penerbit, tahun terbit), cetakan, volume, juz, halaman. Contoh: Soerjono Soekanto, Pokok-pokok Sosiologi Hukum, (Jakarta: Rajawali Pers, 1986), h. 10.

2) Buku terjemahan, contoh: Roscoe Pound, Pengantar Filsafat Hukum: Buku III, diterjemahkan oleh Moh. Radjab, (Jakarta: Bharata, 1963), h. 15;

1) Jurnal, contoh: Nur Rohim, "Kontroversi Pembentukan Perppu No. 1 Tahun 2013 tentang mahkamah konstitusi dalam ranah kegentingan yang memaksa", dalam Jurnal Cita Hukum, Vol. 2, No. 1 (2014), h. 157.

2) Artikel sebagai bagian dari buku (antologi), contoh: Hikmahanto Juwana, "Penegakan Hukum dalam Kajian Law and Development: Problem dan Fundamen bagi Solusi Indonesia", dalam Muhammad Tahir Azhary, Beberapa Aspek Hukum Tata Negara, Hukum Pidana, dan Hukum Islam, (Jakarta: Kencana Prenada Media Gorup, 2012), h. 127.

3) Artikel dari internet, contoh: Ahmad Tholabi Kharlie, "Problem Yuridis RUU Syariah" dalam http://ahmadtholabi.com/2008/03/03/problem-yuridis-ruu-syariah, diunduh pada 20 Maret 2012.

4) Artikel dari majalah, contoh: Susilaningtias, "Potret Hukum Adat pada Masa Kolonial", dalam Forum Keadilan, №. 17, 20 Agustus 2006.

5) Makalah dalam seminar, contoh: Jimly Asshiddiqie, "Kedudukan Mahkamah Konstitusi dalam Struktur Ketatanegaraan Indonesia", Makalah disampaikan dalam Kuliah Umum Fakultas Hukum Universitas Sebelas Maret, Surakarta, pada 2 Maret 2004.

j. Pustaka Acuan: daftar pustaka acuan ditulis sesuai urutan abjad, nama akhir penulis diletakkan di depan. Contoh:

1) Buku, contoh: Soekanto, Soerjono, Pokok-pokok Sosiologi Hukum, Jakarta: Rajawali Pers, 1986.

2) Buku terjemahan, contoh: Pound, Roscoe, Pengantar Filsafat Hukum: Buku III, diterjemahakan oleh Moh. Radjab, Jakarta: Bharata, 1963.

3) Jurnal, contoh: Rohim, Nur, "Kontroversi Pembentukan Perppu No. 1 Tahun 2013 tentang mahkamah konstitusi dalam ranah kegentingan yang memaksa", dalam Jurnal Cita Hukum, Vol. 2, No. 1 (2014).

4) Artikel sebagai bagian dari buku, contoh: Juwana, Hikmahanto, "Penegakan Hukum dalam Kajian Law and Development: Problem dan Fundamen bagi Solusi Indonesia", dalam Muhammad Tahir Azhary, Beberapa Aspek Hukum Tata Negara, Hukum Pidana, dan Hukum Islam, Jakarta: Kencana Prenada Media Gorup, 2012.

5) Artikel yang dikutip dari internet, contoh: Kharlie, Ahmad Tholabi, "Problem Yuridis RUU Syariah" dalam http://ahmadtholabi.com/2008/03/03/problem-yuridis-ruu-syariah, diunduh pada 20 Maret 2012.

6) Majalah, contoh: Susilaningtias, "Potret Hukum Adat pada Masa Kolonial", dalam Forum Keadilan, No. 17, 20 Agustus 2006.

7) Makalah dalam seminar, contoh: Asshiddiqie, Jimly, "Kedudukan Mahkamah Konstitusi dalam Struktur Ketatanegaraan Indonesia", Makalah disampaikan dalam Kuliah Umum Fakultas Hukum Universitas Sebelas Maret, Surakarta, pada 2 Maret 2004.

k. Penutup: artikel ditutup dengan kesimpulan;

I. Biografi singkat: biografi penulis mengandung unsur nama (lengkap dengan gelar akademik), tempat tugas, riwayat pendidikan formal (S1, S2, S3), dan bidang keahlian akademik;

6. Setiap naskah yang tidak mengindahkan pedoman penulisan ini akan dikembalikan kepada penulisnya untuk diperbaiki.

7. Naskah sudah diserahkan kepada penyunting, selambat-lambatnya tiga bulan sebelum waktu penerbitan (Juni dan Desember) dengan mengupload pada laman OJS jurnal pada alamat Website: http://www.jurnalfai-uikabogor.org/index.php/mizan atau dikirim langsung via e-mail ke: jurnalmizan.uikabogor@gmail.com atau syarifah@fai-uika.ac.id. Permalink: https://uikabogor.academia.edu/JurnalMizanUIKABogor.[] 


\section{Mizan}

MIZAN; JURNAL ILMU SYARIAH (ISSN: 2089-032X) adalah berkala ilmiah yang diterbitkan oleh Program Studi Akhwal al Syakhsyiyyah, Fakultas Agama Islam Universitas Ibn Khaldun Bogor. Mizan; Jurnal IImu Syariah mengkhususkan diri dalam pengkajian ilmu-ilmu Syariah, Hukum Keluarga dan Studi Islam. Terbit dua kali dalam satu tahun di setiap bulan Juni dan Desember.

Redaksi menerima artikel-artikel dari para sarjana, pemerhati, dan peneliti dalam bidang IImu Syariah untuk dipublikasikan setelah proses seleksi yang ketat, telaah mitra bestari, serta proses penyuntingan secara serius. Secara substantif, setiap artikel yang dipublikasikan dalam berkala ilmiah ini merupakan pandangan dan sekaligus akan dipertanggungjawabkan secara ilmiah oleh para penulisnya.

ARTIKEL-ARTIKEL MIZAN; JURNAL ILMU SYARIAH TELAH TERINDEKS DAN ONLINE PADA:

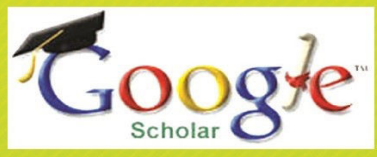

